\title{
APLIKASI E-LEARNING PADA SMK NEGERI KUNDUR BERBASIS WEB
}

\author{
Ade Winarni ${ }^{1}$, Yafri ${ }^{2}$, Reno Kurniawan ${ }^{3 *}$ \\ 1,3 Jurusan Teknik Informatika STT Indonesia Tanjungpinang \\ Jln. Pompa Air No. 28 Tanjungpinang Kepulauan Riau Indonesia \\ 1adewina16@gmail.com \\ 2yafri2301@gmail.com \\ ${ }^{3}$ reno14@gmail.com
}

\begin{abstract}
Intisari- Selama ini semua proses pembelajaran di SMK Negeri Kundur masih bersifat konvensional, dengan kata lain bahwa proses belajar mengajar antara siswa dengan guru hanya dapat dilakukan dengan syarat terjadinya pertemuan antara siswa dengan guru di dalam kelas. Jika pertemuan antara siswa dengan guru tidak terjadi atau guru yang bersangkutan tidak hadir dan waktu pembelajaran yang dibatasi pihak sekolah, maka secara otomatis proses pembelajaran pun akan terhambat. Berbagai konsep dan teknik baru dalam pengajaran telah banyak dikembangkan untuk menggantikan metode tradisional yang hanya mengandalkan pada metode pengajaran satu arah di kelas. Salah satu metode pengajaran yang sedang berkembang di masa sekarang adalah e-learning. E-learning dapat membantu para pengajar dalam mendistribusikan bahan ajar mereka tanpa harus berada di kelas dengan menggunakan internet, hal ini dapat memaksimalkan waktu pembelajaran di kelas yang terbatas. Pengembangan sistem informasi dalam pembuatan perangkat lunak menggunakan metode Waterfall. Metode pengumpulan data yang digunakan dalam penelitian ini adalah observasi, interview atau wawancara dengan topik yang akan diambil dan studi kepustakaan. Untuk merancang aplikasi ini digunakan metode perancangan struktural yaitu pembuatan flowmap, diagram Konteks dan pembuatan Data Flow Diagram (DFD) untuk merancang dan mendokumentasikan sistem perangkat lunak berdasarkan aliran data. Dalam pembuatan perangkat lunak ini menggunakan PHP sebagai bahasa script yang digunakan untuk membuat halaman website dan MySQL sebagai database tempat penyimpanan data. Program diuji dengan melakukan pengujian program dengan memasukan data-data yang telah ada dengan menggunakan metode White Box dan Black Box. Dengan adanya e-learning ini dapat membantu proses belajar mengajar agar lebih optimal. Memudahkan para guru untuk dapat mendistribusikan materi pelajaran untuk siswa di SMK Negeri Kundur dan juga siswa dapat dengan mudah mendapat materi pelajaran. Website e-learning ini dapat dijadikan media diskusi tambahan untuk membahas materi pelajaran yang belum tuntas serta dapat mengerjakan soal-soal latihan dan mengumpulkan tugas-tugas yang di berikan oleh guru.
\end{abstract}

Kata kunci- Aplikasi, E-learning, SMK Negri Kundur, Web.

Abstract - The development of highly advanced technology in the modern era and globalization allows various activities to be carried out quickly and efficiently. Technological developments have had an influence on the way of life of humans, one of which is in the field of education with the use of e-learning in learning activities in schools and colleges.

E-learning (electronic learning) is a learning concept that is carried out through media networks designed with media that can be accessed from computer terminals or different devices that are compatible with technological means that can access websites on a web browser with an Internet network.

SMK Negeri Kundur is a public education institution that provides vocational education at the secondary education level as a continuation of SMP / MTS with agribusiness expertise programs in plantation crop production, agricultural mechanization, computer informatics engineering, electronic engineering, and building engineering which is located on Jl.Besar Sawang Km. .14 Kel. Sawang Selatan, Kec. Kundur Barat. SMK Negeri Kundur is one of the educational institutions that still uses conventional methods as a learning process, where the learning method is carried out face-to-face between teachers and students, the use of technology in classrooms such as computers and other multimedia tools is limited to subjects that need it, as well as teaching materials in the form of a printed text book.

Based on the author's observations made at SMK Negeri Kundur, the problem posed by SMK Negeri Kundur is the limited interaction between students and teachers in the classroom due to the teaching and learning process taught by learning hours at school, the limited teaching materials in the form of printed books, causing students find it difficult to understand the subject matter.

Therefore, the authors are interested in creating a web-based e-learning application. With the use of e-learning at SMK Negeri Kundur, it is hoped that it will solve the problem of limited student learning hours at school and the limited teaching materials that are still in the form of printed textbooks, because e-learning can be used as a learning support tool that can be accessed anytime and anywhere and eliminating limits on learning hours at school so that it can streamline and complement those of conventional learning methods. Keywords-Aplikasi, E-learning, SMK Negri Kundur, Web.

\section{Pendahuluan}

Perkembangan teknologi yang sangat maju di era modern dan globalisasi memungkinkan berbagai kegiatan dilakukan secara cepat dan efisien. Perkembangan teknologi sudah banyak memberi pengaruh terhadap cara hidup manusia, salah satunya adalah dalam bidang pendidikan dengan penggunaan 
e-learning dalam kegiatan pembelajaran di sekolah maupun perguruan tinggi.

E-learning (electronic learning) merupakan konsep pembelajaran yang dilakukan melalui jaringan media elektronik didesain dengan media yang dapat diakses dari terminal komputer atau perangkat berbeda yang sesuai dengan sarana teknologi yang dapat mengakses website pada web browser dengan jaringan Internet.

SMK Negeri Kundur merupakan lembaga pendidikan negeri yang menyelenggarakan pendidikan kejuruan pada jenjang pendidikan menengah sebagai lanjutan dari SMP/MTS dengan program keahlian agribisnis produksi tanaman perkebunan, mekanisasi pertanian, teknik komputer informatika, teknik elektronika, dan teknik bangunan yang terletak di Jl.Besar Sawang Km.14 Kel.Sawang Selatan Kec.Kundur Barat. SMK Negeri Kundur adalah salah satu lembaga pendidikan yang masih menggunakan metode konvensional sebagai proses pembelajaran, dimana metode pembelajaran di lakukan melalui tatap muka antara guru dengan siswa, penggunaan teknologi dalam ruang kelas seperti komputer dan alat multimedia lainnya terbatas pada mata pelajaran tertentu yang membutuhkannya, juga bahan ajar yang berupa buku teks cetak.

Berdasarkan pengamatan penulis yang dilakukan pada SMK Negeri Kundur, masalah yang dihadapi oleh SMK Negeri Kundur adalah terbatasnya interaksi antara murid dengan guru di dalam kelas dikarnakan proses belajarmengajar yang dibatasi oleh jam belajar di sekolah, terbatasnya bahan ajar yang berupa buku teks cetak, sehingga menyebabkan siswa sulit untuk memahami materi pelajaran.

Maka dari itu penulis tertarik untuk membuat aplikasi elearning berbasis web. Dengan penggunaan e-learning pada SMK Negeri Kundur, diharapkan akan memecahkan masalah terbabatasnya jam belajar siswa di sekolah serta terbatasnya bahan ajar yang masih berupa buku teks cetak, karena elearning dapat digunakan sebagai sarana pendukung pembelajaran yang bisa diakses kapan saja dan dimana saja dan mengeliminasi batasan jam belajar di sekolah sehingga dapat mengefektifkan dan melengkapi kekurangan yang ada pada metode pembelajaran konvensional.

\section{Metodologi Penelitian}

\subsection{Konsep Dasar Aplikasi}

Dalam melakukan perancangan suatu aplikasi diperlukan pemahaman terlebih dahulu mengenai pengertian aplikasi, klasifikasi aplikasi serta apa saja yang harus di hindari dalam membuat sebuah aplikasi.

\subsubsection{Definisi Aplikasi}

Perangkat lunak aplikasi adalah suatu sub kelas perangkat lunak komputer yang memanfaakan kemampuan komputer langsung untuk melakukan suatu tugas yang diinginkan pengguna. Biasanya dibandingkan dengan perangkat lunak sistem yang mengintegrasikan berbagai kemampuan komputer, tapi tidak secara langsung menerapkan kemampuan tersebut untuk mengerjakan suatu tugas yang menguntungkan pengguna. Contoh utama perangkat lunak aplikasi adalah pengolah kata, lembar kerja, dan pemutar media.
Beberapa aplikasi yang digabung bersama menjadi suatu paket kadang disebut sebagai suatu paket atau suite aplikasi (application suite). Contohnya adalah Microsoft Office dan OpenOffice.org, yang menggabungkan suatu aplikasi pengolah kata, lembar kerja, serta beberapa aplikasi lainnya. Aplikasi-aplikasi dalam suatu paket biasanya memiliki antarmuka pengguna yang memiliki kesamaan sehingga memudahkan pengguna untuk mempelajari dan menggunakan tiap aplikasi. Sering kali, mereka memiliki kemampuan untuk saling berinteraksi satu sama lain sehingga menguntungkan pengguna. Contohnya, suatu lembar kerja dapat dibenamkan dalam suatu dokumen pengolah kata walaupun dibuat pada aplikasi lembar kerja yang terpisah.

\subsubsection{Klasifikasi Aplikasi}

Aplikasi dapat digolongkan menjadi beberapa kelas, antara lain:

1. Perangkat lunak perusahaan (enterprise) terdiri dari perangkat lunak akuntansi, bagian pendukung (back office), perangkat lunak bisnis, dan manajemen sumber daya manusia.

2. Perangkat lunak infrastruktur perusahaan terdiri dari perangkat lunak alur kerja bisnis, sistem manajemen basis data, manajemen aset digital, dan manajemen dokumen.

3. Perangkat lunak informasi kerja terdiri dari manajemen waktu dan sumber daya, manajemen data, dokumen, perangkat lunak analitik, dan perangkat lunak kolaborasi.

4. Perangkat lunak media dan hiburan terdiri dari media digital dan perangkat lunak hiburan.

5. Perangkat lunak pendidikan manajemen ruang kelas, manajemen survei, manajemen pelatihan, dan perangkat lunak kesiapan penjualan.

6. Perangkat lunak pengembangan media terdiri dari perangkat lunak seni grafis dan penyuntingan media.

7. Perangkat lunak rekayasa produk terdiri dari rekayasa perangkat keras dan rekayasa perangkat lunak.

Pada pengertian umumnya, aplikasi adalah alat terapan yang difungsikan secara khusus dan terpadu sesuai kemampuan yang dimilikinya aplikasi merupakan suatu perangkat komputer yang siap pakai bagi pengguna.

\subsubsection{Jenis-jenis Aplikasi}

Program aplikasi pada komputer merupakan perangkat lunak siap pakai yang nantinya akan digunakan untuk membantu melaksanakan pekerjaan pengguna. Dalam sebuah komputer aplikasi ini disiapkan sesuai kebutuhannya masingmasing. Berikut ini adalah program aplikasi yang dapat dibedakan lagi beberapa macam:

1 Spreadsheet, Software yang digunakan untuk mengolah informasi keuangan atau data-data dalam bentuk tabulasi.

2 Data manajemen, Software yang digunakan untuk menyimpan, menghasilkan dan memanipulasi data. Ada dua jenis data manajemen, yaitu filing program dan database management system.

3 Word Processing, Software yang digunakan untuk mengolah teks contohnya aplikasi Office. Pemroses kata umum di gunakan untuk menggantikan tugas pengetikan yang sering di lakukan. Selain dapat melakukan format pengetikan seperti penomoran, pengaturan spasi, jarak pinggir kertas 
(margin), jenis huruf (font), pemroses kata juga dapat melakukan proses pengecekan kata bahkan kalimat.

4 Excel : Program Pemproses Tabel, Pemroses tabel biasanya di gunakan untuk melakukan perhitungan yang menggunakan tabel (tabulasi).

5 Desktop Publishing, Software yang digunakan dalam bisnis penerbitan untuk pembuatan dan pengolahan citra, seperti diagram, gambar, peta, fotografi, dan sebagainya.

6 Multimedia, Software yang menyajikan informasi dalam berbagai bentuk penampilan, seperti teks, musik, suara, atau film. Terdapat dua jenis software multimedia, yaitu presentation dan intercative. Penyajian informasi dalam presentation bersifat sekuensial seperti dalam TV atau bioskop, sementara penyajian informasi dalam interactive dalam mengikuti kehendak pemakai melalui media interaksi yang disediakan.

7 Aplikasi multimedia, Saat ini sangat banyak dan beragam. Di katakan multimedia karena selain penggunaan media teks, aplikasi ini dapat memproses / menampilkan dalam bentuk yang lain yaitu gambar, suara dan film.

8 Communication Software, Komputer seringkali saling terhubung dalam rangka untuk membagi atau mengaitkan informasi. Untuk pertukaran informasi ini, komputer menggunakan communication software.

9 Aplikasi Internet, Perangkat lunak yang berhubungan dengan internet sangat berkaitan dengan aplikasi internet. Aplikasi internet adalah protokol yang digunakan untuk berhubungan antara satu orang atau mesin dengan pihak lain yang berjauhan. Aplikasi internet akan menyangkut dua sisi, yaitu sisi penyedia (server) atau sisi pengguna (client).

10 Workgroup Software, Workgroup software atau groupware membantu kelompok atau team untuk bekerja sama dengan cara menyediakan informasi yang dapat digunakan bersama melalui workflow di dalam kelompok tersebut.

11 Integrated Enterprise Software, Enterpise software terdiri dari program-program yang mengatur operasi-operasi vital sebuah perusahaan. Integrated enterprise software mendukung supply chain management, human resource management, dan financial management. Software ini kerap kali dikenal sebagai enterpise resource planning (ERP).

\subsection{Website}

Website adalah halaman informasi yang disediakan melalui jalur internet sehingga bisa di akses di mana pun selama terkoneksi dengan jaringan internet. Website merupakan komponen atau kumpulan komponen yang terdiri dari teks, gambar, suara, animasi, sehingga lebih merupakan media informasi yang menarik untuk di kunjungi.

Berdasarkan kategorinya, website digolongkan menjadi 3:

1. Website Statis: website yang mempunyai halaman tidak berubah. Artinya adalah untuk melakukan perubahan pada suatu halaman dilakukan secara manual dengan mengedit kode yang menjadi struktur dari website tersebut.

2. Website Dinamis: website yang secara struktur diperuntukkan untuk update sesering mungkin. Biasanya selain halaman utama yang di akses oleh pengguna pada umumnya, juga di sediakan halaman backend untuk mengubah konten dari website. Contoh umum mengenai website dinamis adalah web berita atau web portal yang di dalamnya terdapat fasilitas berita, poling dan sebagainya.

3. Website Interaktif: pengguna bisa berinteraksi dan beradu argumen mengenai pemikiran dan pengetahuan. Biasanya website interaktif memiliki moderator untuk mengatur supaya topik yang diperbincangkan tidak keluar jalur.

\subsubsection{Perkembangan Web}

Perkembangan web saat ini demikian cepat, hal ini disebabkan oleh beberapa faktor di antaranya perkembangan infrastruktur pendukung yang cukup pesat seperti internet, kebutuhan pelaku industri untuk menggunakan web dan internet sebagai layanan tambahan dalam bisnis mereka, masyarakat yang memandang internet dan website saat ini sebagai kebutuhan dalam semua aspek kehidupan mereka khususnya masyarakat modern di perkotaan

Tim Berners-Lee pada tahun 1989 menemukan metode baru dalam menghubungkan dokumen satu dengan lainya di internet. Selanjutnya metode ini dikembangkan terus sehingga menjadi sebuah web. Pada tahun 1993 web browser yang berbasis grafis ditemukan oleh Marc Andreessen, seorang peneliti di National Center for Supercomputing Applications. Nama web browser-nya adalah Mosaic. Pada tahun 1944, Marc Andreessen mengembangkan Mosaic menjadi sebuah web browser Netscape. Pada saat itu juga Microsoft mengeluarkan produk web browser pertama mereka yaitu Internet Explorer. Saat ini perkembangan web dan relasinya dipercayakan pada sebuah lembaga nirlaba yang berpusat di Amerika, yaitu World-Wide-Web Consortium atau W3C (WWW.W3.org) . Lembaga ini adalah tempat berkumpulnya peneliti dan pengambil kebijakan yang berhubungan dengan web di seluruh dunia. Lembaga ini juga memiliki sebuah situs web yang sering dijadikan referensi untuk belajar secara online (e-learning) yaitu www.w3schools.com.

\subsection{Aplikasi Berbasis Web}

Yang dimaksud dengan aplikasi web atau aplikasi berbasis web adalah aplikasi yang dijalankan melalui browser. Aplikasi seperti ini pertama kali dibangun hanya dengan menggunakan bahasa yang disebut dengan HTML (HyperText Markup Language) dan protokol yang digunakan dinamakan HTTP (HyperText Transfer Protokol). Namun, tentu saja hal seperti ini memiliki kelemahan. Semua perubahan harus dilakukan pada tingkatan aplikasi. Pada perkembangan berikutnya, sejumlah skrip dan objek dikembangkan untuk memperluas kemampuan HTML. Banyak skrip diantaranya yaitu PHP, ASP, ASP.NET sedangkan contoh yang berupa objek antara lain adalah applet (Java).

Dengan mengembangkan kemampuan HTML, yakni dengan menggunakan perangkat lunak tambahan, perubahan informasi dalam halaman-halaman web dapat ditangani melalui perubahan data bukan melalui program. Sebagai implementasinya, aplikasi web dapat dikoneksikan ke database. Dengan demikian, perubahan informasi dapat dilakukan oleh operator atau yang bertanggung jawab terhadap kemutakhiran data dan tidak menjadi tanggung jawab pemrogram atau web master. Konsep yang mendasari aplikasi web sebenarnya sederhana. Operasi yang 
melatarbelakanginya melibatkan pertukaran informasi antara komputer yang meminta informasi yang disebut client dan komputer yang memasok informasi (server).

Secara lebih detail, server yang melayani permintaan dari client sesungguhnya berupa suatu perangkat lunak yang dinamakan webserver. Secara internal, webserver inilah yang berkomunikasi dengan perangkat lunak lain yang disebut middleware dan middleware inilah yang berhubungan dengan database. Dengan menggunakan web dinamis, dimungkinkan untuk membentuk aplikasi berbasis web yang berinteraksi dengan database.

\subsection{E-learning}

E-learning adalah pembelajaran jarak jauh (distance learning) yang memanfaatkan teknologi internet. E-learning memungkinkan siswa untuk belajar melalu komputer di tempat masing-masing tanpa harus secara fisik mengikuti pelajaran di kelas. Beberapa pengertian yang berkaitan dengan e-learning adalah pembelajaran jarak jauh, pembelajaran dengan perangkat komputer, pembelajaran formal atau ingormal, dan pembelajaran yang ditunjang oleh para ahli.

\section{HASIL DAN PEMBAHASAN}

a. Perancangan Prosedur Usulan E-Learning SMK Negeri Kundur

1. Tata usaha mengolah data guru, siswa, tata usaha, kepala sekolah, jurusan, pelajaran.

2. Tata usaha cetak laporan data siswa, guru, dan tata usaha untuk di serahkan kepada kepala sekolah.

3. Tata usaha membuat pengumuman yang di tujukan untuk seluruh pengguna $e$ learning SMK Negeri Kundur.

4. Kepala sekolah membuat pemberitahuan yang di tujukan kepada seluruh guru dan tata usaha.

5. Guru mengolah data pelajaran dan memberikan tugas kepada siswa sesuai data pelajaran dan jurusan yang telah di buat oleh tata usaha untuk siswa.

6. Siswa mengolah data jawaban soal yang telah di berikan oleh guru.
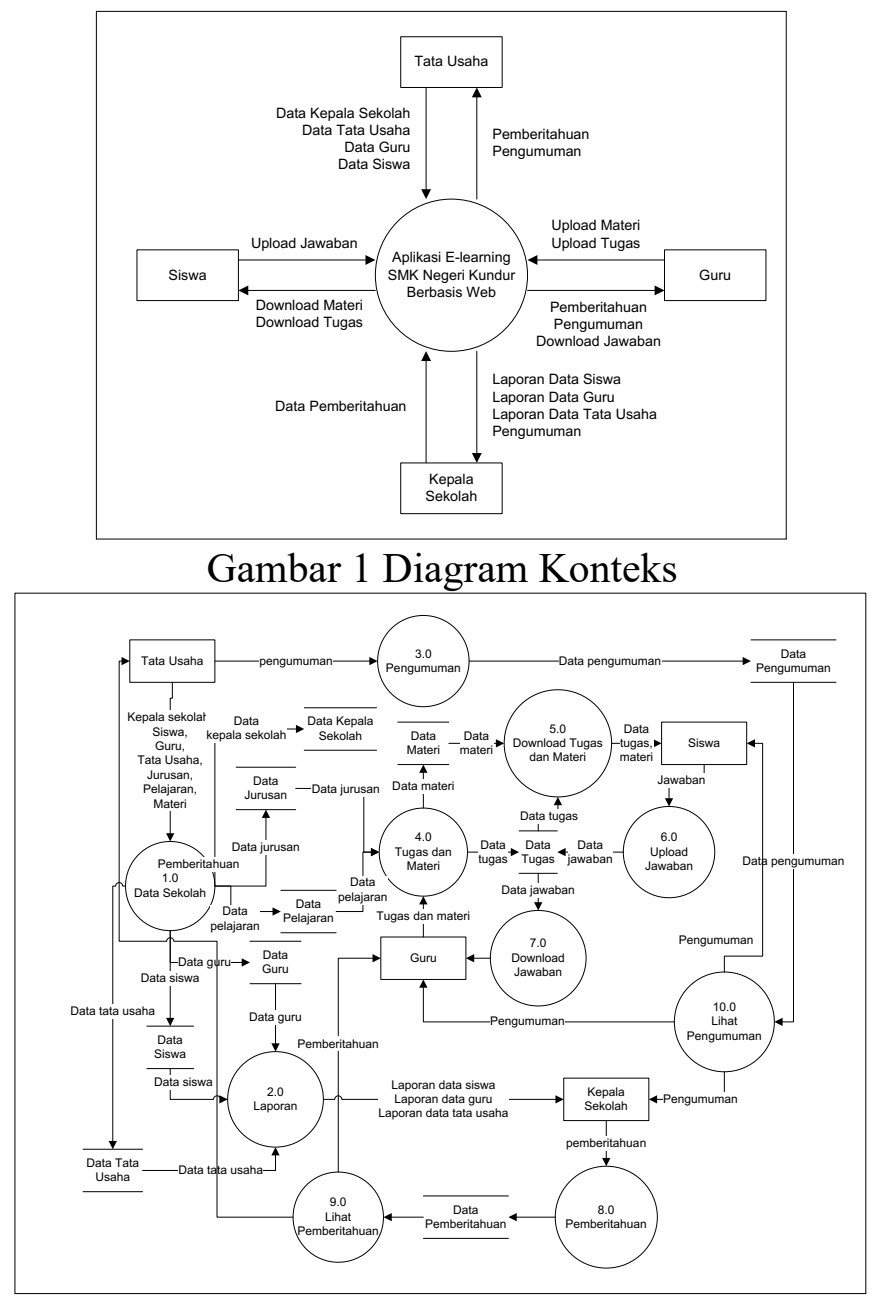

Gambar 2 Data Flow Diagram (DFD) Level 0

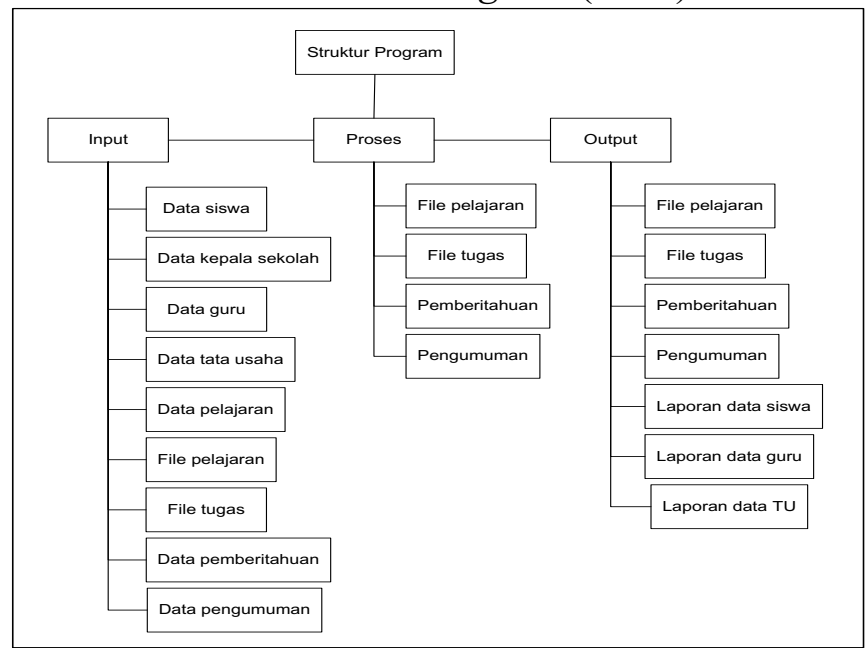

Gambar 3 Struktur Program 


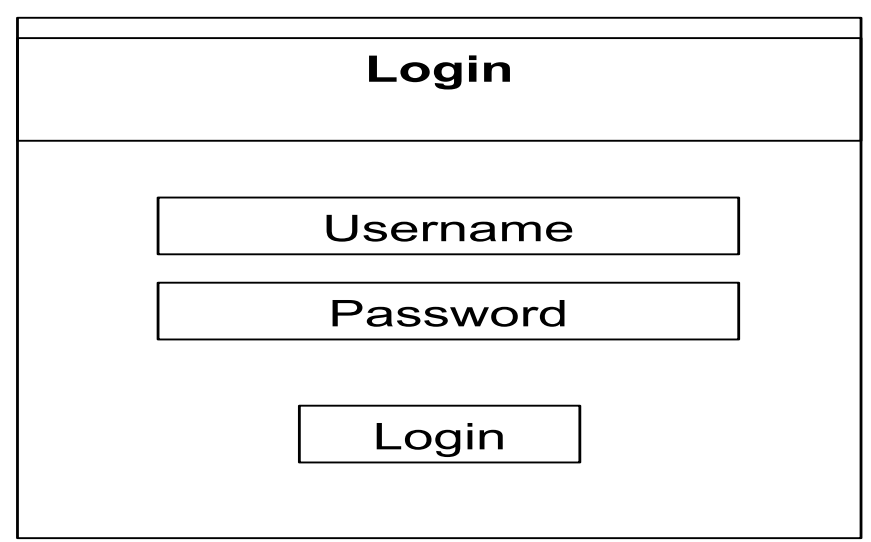

Gambar 4 Perancang Halaman Login

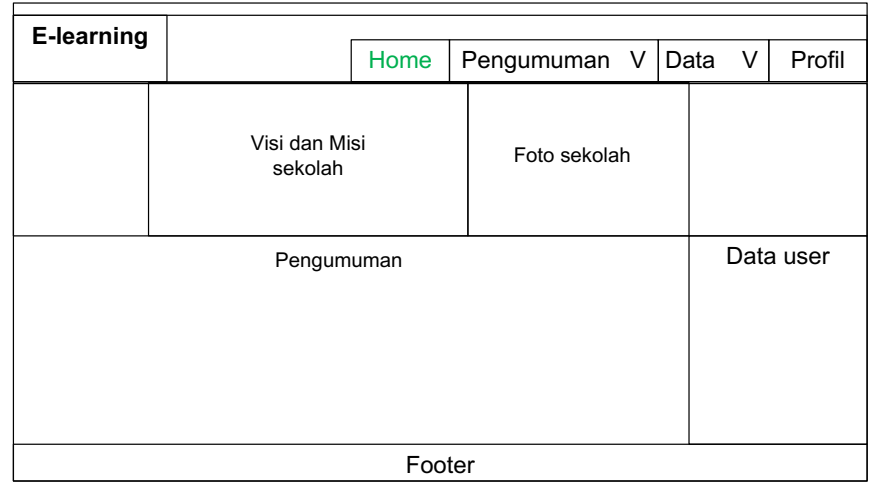

Gambar 5 Perancangan Halaman Home Tata Usaha

b. Hasil

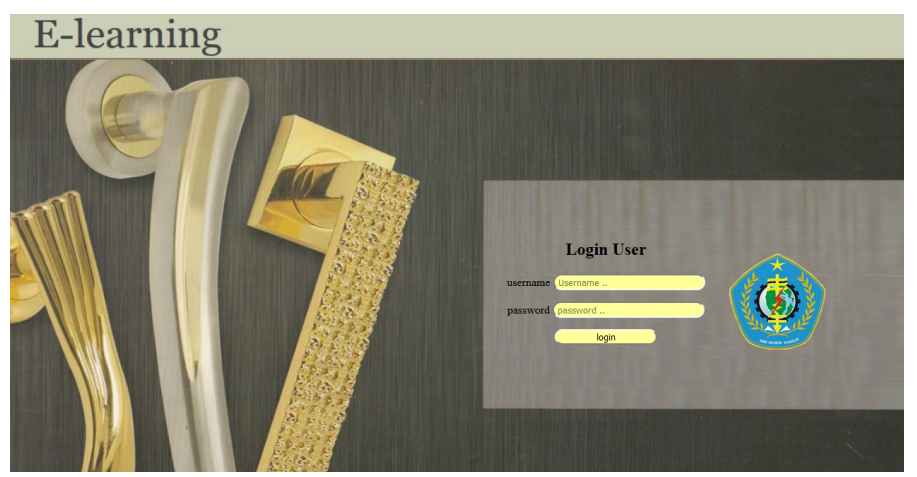

Gambar 6 Halaman Login

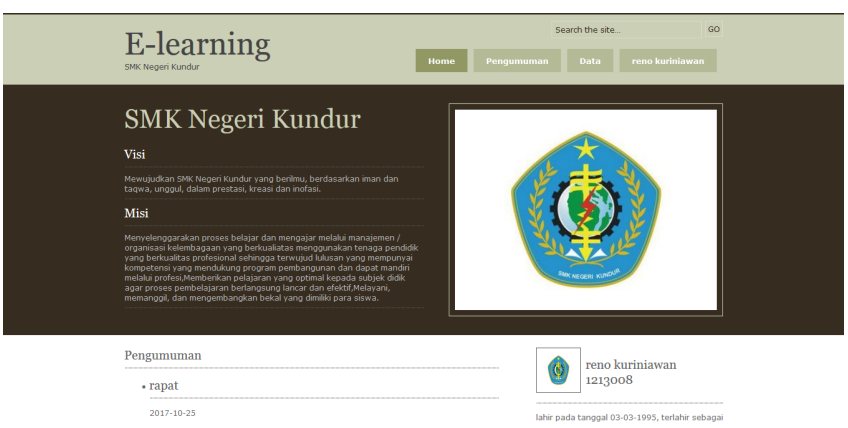

Gambar 7 Halaman Home Tata Usaha

\section{KESIMPULAN}

Kesimpulan merupakan ringkasan yang diambil dari pembahasan sistem yang dibuat. Dari perancangan Aplikasi E-learning SMK Negri Kundur Berbasis Web maka didapat beberapa kesimpulan, diantaranya adalah sebagai berikut :

1. Guru dapat memberikan tugas sekolah atau PR kepada siswa melalui $e$ learning di saat guru berhalangan hadir.

2. Seluruh siswa dapat memiliki bahan ajar atau materi pelajaran dengan mengunduh/download file pelajaran yang telah di unggah/upload oleh guru pada e-learning.

3. Siswa dapat mengakses e-learning dimana saja dan kapan saja untuk mengakses file pelajaran ataupun tugas sekolah atau PR.

4. Siswa dapat mengunggah/upload file tugas atau PR yang telah selesai di kerjakan.

5. Pengguna e-learning dapat melihat pengumuman dan pemberitahuan dari tata usaha dan kepala sekolah.

\section{REFERENSI}

Adelheid Andrea, Website No.1 : Cara Mudah Bikin Website \& Promosi Ke Seo, 2015, Yogyakarta.

Andi, Pemrograman PHP dan MySQL Untuk Pemula, 2016, Yogyakarta.

Arief M.Rudianto, Pemrograman Web Dinamis Menggunakan PHP \& MySQL, 2011, Yogyakarta.

Jusak, Teknologi Komunikasi Data Modern, 2013, Yogyakarta.

Larry Roy, Jurus Kilat Mahir HTML dan CSS, 2012, Jakarta Timur.

Presman, Roger, Rekayasa Perangkat Lunak Pendekatan Praktisi, 2012, Yogyakarta. 
Bangkit Indonesia, Vol. VI, No. 02, Bulan Oktober 2017

Purbadian Yenda, Aplikasi Penjualan Web Base Dengan PHP Untuk Panduan Skripsi, 2015, Cirebon.

Solichin Achmad, Pemrograman Web Dengan PHP dan MySQL, 2016, Jakarta.

Suryana Taryana, Koesheryatin, Aplikasi Internet Menggunakan HTML, CSS \& JavaScript, 2014, Jakarta.

t.p, Mengenal Java dan Database Dengan NetBeans, 2015, Jakarta.
Yakub, Pengantar Sistem Informasi, 2012, Yogyakarta.

Yesin Verdi,S.Kom, Rekayasa Perangkat Lunak Berorientasi Objek Pemodelan, Arsitektur dan Perancangan (Modeling, Architecture and Design), 2012, Jakarta. 